\title{
Technological properties of precooked flour containing coffee powder and rice by thermoplastic extrusion
}

\author{
Caracterização tecnológica de misturas pré-cozidas de arroz com café por extrusão termoplástica
}

\author{
Reginaldo Ferreira da SILVA ${ }^{1 *}$, Rosemary Gualberto Fonseca Alvarenga PEREIRA², \\ José Luis Ramirez ASCHERI ${ }^{3}$, Diego Palmiro Ramirez ASCHERI ${ }^{4}$
}

\begin{abstract}
Although Brazil is a country of tradition in both the production and consumption of coffee, the most of the coffee is consumed as a beverage, which reduces greatly the competitiveness on international market, for reducing the chances of supplying the product under other forms of consumption. Owing to that, the aim of this study was developing a precooked mixed flour containing coffee powder and rice for use in coffee flavored products. Mixtures of rice and coffee in the proportions of 900:100, 850:150 and 800:200 g, respectively, were processed in a single screw extruder (Brabender DS-20, Duisburg, German) and the effect of the extrusion process on the variables moisture content (16\%, $18 \%$ and $20 \%)$ and temperature in the third extruding zone $\left(140^{\circ} \mathrm{C}, 160^{\circ} \mathrm{C}\right.$ and $\left.180{ }^{\circ} \mathrm{C}\right)$ was studied. The results for expansion index ranged from 2.91 to $11.11 \mathrm{~mm}$ in diameter; the water absorption index from 4.59 to $6.33 \mathrm{~g}$ gel/g sample and the water solubility index varied from $4.05 \%$ to $8.57 \%$. These results showed that, despite coffee powder influenced the variables studied, the expanded product after milling resulted in a extruded mixture with good absorption and water solubility indices, which favors the use of the precooked mixed flour for human consumption. Keywords: extrusion; rice; coffee; mixtures; technological properties.
\end{abstract}

\section{Resumo}

O Brasil é um país de tradição na produção e consumo de café, porém, parte do consumo do café é na forma de bebida. O objetivo deste estudo foi elaborar uma farinha mista instantânea de pó de café com arroz para uso no preparo de bebidas e produtos panificáveis como bolos e biscoitos tipo cookies com sabor de café. Misturas nas proporções de 900:100, 850:150 e 800:200 g de arroz e café, respectivamente, foram processadas em uma extrusora Brabender DS-20 (Duisburg, Alemanha) de parafuso simples, e foi estudado o efeito do processo de extrusão das variáveis umidade da mistura $(16 \%, 18 \%$ e $20 \%)$ e temperatura na $3^{\circ}$ zona $\left(140,160\right.$ e $\left.180{ }^{\circ} \mathrm{C}\right)$. Os resultados observados para as variáveis respostas, índice de expansão, com valores encontrados entre 2,91 e 11,11 mm de diâmetro; índice de absorção de água, com valores variando entre 4,59 a 6,33 g de gel. $\mathrm{g}^{-1}$ de amostra; e índice de solubilidade em água, com valores encontrados entre 4,05\% e 8,57\%, mostraram que o alto teor de fibras totais $(14,22 \%)$ presentes no pó de café provocou uma redução da expansão dos extrusados e, consequentemente, nas propriedades tecnológicas das misturas elaboradas com arroz. Porém, o produto expandido após moagem resultou em um pó de alta solubilidade, o que favorece o seu uso como farinha pré-cozida na alimentação humana.

Palavras-chave: extrusão; arroz; café; mistura; propriedades tecnológicas.

\section{Introduction}

Coffee is an important product in the Brazilian export agenda. It is a great employment generator and fixer of labor force in the field. It is estimated that it employs about four million people in its production, but considering all the segments involved (production, industry, commerce and services), this number reaches 10 million (CENÁRIO, 2001).

According to ABIC (ASSOCIAÇÃO..., 2012), the Brazilian domestic consumption of green coffee keeps on growing in a marked way. In 2010, the consumption was $4.81 \mathrm{~kg}$ per inhabitant, a volume that overcomes the $4.72 \mathrm{~kg}$ recorded in 1965 by IBC (Brazilian Coffee Institute), up to the greatest already recorded value. That result arises from the annual evaluation performed by ABIC in "Indicators of the Coffee
Industry in Brazil in 2010. These results were estimated by the research area that studies "Home Production and Consumption Performance", which analyzed industry data from November/2009 to October/2010. In the same way, the per capita consumption of toasted and milled coffee was $4.42 \mathrm{~kg}$, almost $74 \mathrm{~L}$ per Brazilian inhabitant per year, recording a growth of $3.5 \%$ in the previous period, which was $4.5 \%$ in the last survey. ABIC ascribed the consumption growth to a number of factors that has been repeating for years in a lasting and consistent way, such as the continuous improvement of coffee quality, market consolidation of type Gourmet or Special coffees, growth of outof-home consumption, perception on health benefits of coffee, besides the improvement of economic conditions in Brazil.

${ }^{1}$ Centro de Ciências da Saúde e do Desporto, Universidade Federal do Acre - UFAC, Rio Branco, AC, Brasil, e-mail: reginaldo.alimentos@gmail.com

2 Universidade Federal de Lavras - UFLA, Lavras, MG, Brasil

${ }^{3}$ Embrapa Agroindústria de Alimentos, Rio de Janeiro, RJ, Brasil

${ }^{4}$ Universidade Federal de Goiás - UFG, Goiânia, GO, Brasil

${ }^{*}$ Corresponding author 
Another factor that may be related to the growing consumption of coffee in Brazil is its use as an ingredient in the production and diversification of a wide range of food products, such as teas, cakes, puddings, espresso, gourmet, instant, soluble, cappuccino, frappuccino, candies, among others. (ORMOND; PAULA; FAVERET FILHO, 1999). According to Saes and Jayo (1998), it is possible to extract a sort of oil from the coffee bean, which can be used in food and cosmetic industries. Within this context, both industry and research centers are increasingly seeking to provide consumers with potential market niches such as new coffee-based products, resulting in increased consumption.

On the other hand, rice is a starch-containing cereal that besides the consumption in the processed and polished form, it is used to a lesser extent as industrial raw material for the production of breakfast cereals, hypoallergenic products, infant formulas, low calorie foods, sake, pre-gelatinized flours, snacks, starch and others (LUNDUBWONG; SEIB, 2000).

Despite the lower cost, rice flour is produced on a small scale for not presenting competitive application as compared to wheat flour. However, several characteristics of rice flour may be further explored such as: not allergenic; wide range of amylose content of some varieties; safe for people with celiac disease so it may be a substitute for wheat in gluten-free food; soft texture after cooking provided by the small size of starch granules and mild flavor (POLANCO et al., 1995); low levels of sodium and high proportion of easily digestible starches (TORRES et al., 1999).

Extrusion is a cooking and molding process developed in the 1960's to give physical and chemical functionality to food products. At present, important technological parameters for the starch industry such as expansion index, absorption, solubility and viscosity of dough have been used as an alternative in evaluating the use or diversification of products and byproducts for human consumption. Besides the technological purposes, extrusion, in most cases, allows the beneficial effects of nutritional or functional order, since it enables the processing of mixtures of different sources of proteins, fibers and other nutrients. As a result, several studies have been carried out in order to use food sources with nutritive and functional potential, but in most cases are wasted, poorly used or undervalued as a main raw material. As examples of these products, we mention the pre-gelatinized rice flours with jaboticaba peel (ASCHERI et al., 2006); instant soup based on amaranth and broken rice (MENDONÇA, 2005); pre-cooked pasta based on whole quinoa and rice (BORGES et al., 2003); precooked corn and soybean flour (FERNANDES, 2002); instant flours produced from corn, casein and yeast extract (ALVIM, 2001); porridges rice with soybean hulls (MAIA et al., 1999), among others.

Owing to that, this study aims to extrude mixtures of broken rice and dark-colored coffee powder, both considered low-priced raw materials in commerce and verify through parameters such as expansion index, absorption and solubility in water, the viability of these precooked mixtures to be used as ingredients of bread making products.

\section{Materials and methods}

\subsection{Raw material}

Broken rice packed in $5.0 \mathrm{~kg}$ plastic bags totaling $25.00 \mathrm{~kg}$ and toasted and milled coffee (arabica) obtained by traditional toasting (dark) according to the manufacturer's specification, packed in $500 \mathrm{~g}$ bags totaling $6.0 \mathrm{~kg}$ was used. Both raw materials used in this study were purchased from the market of Campo Grande, Rio de Janeiro. Bean milling for obtaining rice flour was performed in a hammer and knife chipper mill using a mesh sieve with $1 \mathrm{~mm}$ diameter. Shortly after milling, the flour was homogenized for 5 minutes in dough blender type Werner Peleiderer to standardize moisture content. Next, it was packed in plastic bags and stored under refrigeration until the beginning of the extrusion process. The small bags of coffee powder were opened and milled again in a chipper hammer blade mill by using the same sieve in order to obtain a more homogeneous particle size. In the same way, they were packed in plastic bags and stored under refrigeration until the process.

The coffee powder and the rice flour presented the following average composition $\mathrm{g} / 100 \mathrm{~g}$ sample: $4.89 \mathrm{~g}$ and $12.44 \mathrm{~g}$ moisture, $11.60 \mathrm{~g}$ and $0.69 \mathrm{~g}$ lipids, $15.75 \mathrm{~g}$ and $7.32 \mathrm{~g}$ crude protein, $62.92 \mathrm{~g}$ and $79.08 \mathrm{~g}$ total carbohydrates, $4.84 \mathrm{~g}$ and $0.47 \mathrm{~g}$ ash, $14.22 \mathrm{~g}$ and $1.57 \mathrm{~g}$ total fibers and caloric value of $419.08 \mathrm{kcal}$ and $351.81 \mathrm{kcal}$ for the coffee powder and broken rice, respectively.

The preparation of the raw materials was carried out in the Cereal Laboratory, Pilot Plant IV, extrusion sector in Embrapa Food Agroindustry, Rio de Janeiro.

The thermoplastic extrusion process of the mixture containing rice flour and coffee powder was performed in a single screw extruder Brabender, model $20 \mathrm{DN}$, with extrusion system by mechanic friction, temperature control system in the jacket, variable speed and production capacity of $10.5 \mathrm{~kg} \cdot \mathrm{h}^{-1}$. The process parameters were: extrusion temperature in the $1^{\text {st }}$ and $2^{\text {nd }}$ zone, $\left(60\right.$ and $\left.120^{\circ} \mathrm{C}\right)$, respectively; width of the screw $(10 \mathrm{~mm})$; die opening $(3 \mathrm{~mm})$, screw compression rate (3:1) and feeding rate $\left(16 \mathrm{~g} \cdot \mathrm{min}^{-1}\right)$. The independent variables moisture of raw material ( 15 to $21 \%$ ), temperature in the $3^{\text {rd }}$ zone (126 to $194^{\circ} \mathrm{C}$ ), screw rotation (126 to 194 ) and percentage of coffee in the mixture (7 to $23 \%$ ) ranged according to that established in the experimental design.

Expanded samples were collected by hand at the exit of the die so that the extrudate was kept as straight as possible after cooling to room temperature to facilitate the calculation of the expansion index. The extrudates were submitted to dehydration in an oven at $50{ }^{\circ} \mathrm{C}$ for 15 hours and then cooled and milled in disc mill Perten, model 3.600 with a $0.5 \mathrm{~mm}$ sieve, labeled and stored in plastic bags under refrigeration until the analyses.

\subsection{Statistical analyses}

To analyze the combined effect of independent variables on the technological characteristics of the extrudates, a statistically designed experiment in response surface methodology of the second order rotational central type was established 
(ANDERSON et al., 1969). By introducing these designs in the study of second-degree polynomials adjusted to experimental data, we aimed to minimize the number of treatments. The process parameters established as independent variables (moisture of the flour, extrusion temperature and percentage of coffee in the mixture) were investigated at three levels codified at $-1,0$, and +1 .

Through a regression analysis, a second order polynomial can be adjusted to each response (Y) as the explicative variables $\left(\mathrm{X}_{\mathrm{k}}\right)$. The general expression used to predict the behavior of each measured response can be written as follows (Equation 1):

$Y_{i}=\beta_{0}+\beta_{1} X_{1}+\beta_{2} X_{2}+\beta_{3} X_{3}+\beta_{11} X_{1}^{2}+\beta_{22} X_{2}^{2}+\beta_{33} X_{3}^{2}+\beta_{12} X_{1} X_{2}+\varepsilon$

where: $\mathrm{Y}_{\mathrm{i}}=$ response function; $\mathrm{X}_{1}, \mathrm{X}_{2}, \mathrm{X}_{3}=$ independent variables values; $\beta_{0}=$ coefficient relative to the interpretation of the plan with the axis response; $\beta_{1}, \beta_{2}, \beta_{3}=$ linear coefficients estimated by the least squares method; $\beta_{11}, \beta_{23}, \beta_{33}=$ coefficients of the quadratic variables; $\beta_{12}, \beta_{13}, \beta_{23}=$ coefficients of interaction between the independent variables; $\varepsilon=$ experimental error.

The experiment was conducted in a $2^{3}$ full factorial design with three factors or independent variables (temperature, moisture and percent of coffee in the mixture). The complete design is presented in Table 1 . The ranges between the lower and upper limit for each variable were determined by preliminary tests.

The significance of the model was tested by the analysis of variance (ANOVA) by using the F distribution test, whereby a regression model is significant at a certain level of significance when the distribution value of $\mathrm{F}$ calculated test is greater or equal the $\mathrm{F}$ tabulated test at this significance level. The greater

Table 1. Full experimental design of the extrusion process of the mixture of rice flour and coffee powder.

\begin{tabular}{|c|c|c|c|c|c|c|}
\hline \multirow{2}{*}{ Experiment } & \multicolumn{3}{|c|}{$\begin{array}{l}\text { Codified levels of the } \\
\text { variables }\end{array}$} & \multicolumn{3}{|c|}{$\begin{array}{l}\text { Decodified levels of the } \\
\text { variables }\end{array}$} \\
\hline & $\mathrm{X}_{1}$ & $\mathrm{X}_{2}$ & $\mathrm{X}_{3}$ & $\mathrm{U}(\%)$ & $\mathrm{T}\left({ }^{\circ} \mathrm{C}\right)$ & M (\%) \\
\hline 1 & -1.00 & -1.00 & -1.00 & 16 & 140 & 10 \\
\hline 2 & -1.00 & -1.00 & 1.00 & 20 & 140 & 10 \\
\hline 3 & -1.00 & 1.00 & -1.00 & 16 & 180 & 10 \\
\hline 4 & -1.00 & 1.00 & 1.00 & 20 & 180 & 10 \\
\hline 5 & 1.00 & -1.00 & -1.00 & 16 & 140 & 20 \\
\hline 6 & 1.00 & -1.00 & 1.00 & 20 & 140 & 20 \\
\hline 7 & 1.00 & 1.00 & -1.00 & 16 & 180 & 20 \\
\hline 8 & 1.00 & 1.00 & 1.00 & 20 & 180 & 20 \\
\hline 9 & -1.68 & 0.00 & 0.00 & 18 & 160 & 15 \\
\hline 10 & +1.68 & 0.00 & 0.00 & 18 & 160 & 15 \\
\hline 11 & 0.00 & 0.00 & 0.00 & 18 & 160 & 15 \\
\hline 12 & 0.00 & 0.00 & 0.00 & 18 & 160 & 15 \\
\hline 13 & -1.68 & 0.00 & 0.00 & 15 & 160 & 15 \\
\hline 14 & +1.68 & 0.00 & 0.00 & 21 & 160 & 15 \\
\hline 15 & 0.00 & -1.68 & 0.00 & 18 & 126 & 15 \\
\hline 16 & 0.00 & +1.68 & 0.00 & 18 & 194 & 15 \\
\hline 17 & 0.00 & 0.00 & -1.68 & 18 & 160 & 7 \\
\hline 18 & 0.00 & 0.00 & +1.68 & 18 & 160 & 23 \\
\hline
\end{tabular}

$\mathrm{U}=$ Moisture content of the rice flour and coffee powder (\%); $\mathbf{T}=$ Extrusion temperature

$\left({ }^{\circ} \mathrm{C}\right) ; \mathbf{M}=$ mixture of rice flour and coffee powder $(\%)$. the calculated F test, the more predictive the model is (BOX; DRAPER, 1987).

From the regression equation obtained by varying two variables while the third one remains constant, it was possible to design three-dimensional graphics of response surface with the aid of the computer program Basic Statistcs and Tables. Data processing and statistical analysis were assessed by Statistica STATSOFT program (1996).

\subsection{Physical and functional analyses of the extrudates}

\section{Expansion index (IE)}

IE was calculated as the ratio between the diameters of the extrudates $(\mathrm{mm})$ and the diameter of the extruder die $(\mathrm{mm})$. Diameter measurements were done on the surfaces of the uniform sample with the aid of a pachymeter. The value obtained was considered as the arithmetic mean of 10 measurements from each treatment or sample according to the methodology proposed by Faubion, Hoseney and Seib (1982) and calculated by the equation bellow:

\section{$\mathbf{E I}=$ diameter of the extrudates/diameter of the extruder die}

\section{Water absorption index (WAI) and water solubility index (WSI)}

The determinations of WAI and WSI of the extruded precooked flour followed the methodology described by Anderson et al. (1969) and adapted for this study. All determinations were performed in duplicate. For the calculation of WAI, approximately $1 \mathrm{~g}$ sample (with particle size of 150 mesh) and $10 \mathrm{~mL}$ of distilled water at $30^{\circ} \mathrm{C}$ were placed in previously weighed centrifuge tubes. The tubes were shaken for 30 minutes in a mechanical shaker, while keeping at $30^{\circ} \mathrm{C}$ in water bath type Reciprocal Shaking Bath Model 50, followed by centrifugation at $3500 \mathrm{rpm}$ for 15 minutes. The supernatant was placed carefully over a previously weighed Petri dish that was transferred to an oven at $50{ }^{\circ} \mathrm{C}$ until constant weight. The remaining gel (wet sample) was weighed and WAI was calculated according to the formula bellow (Equation 2).

$\mathrm{WAI}=\frac{\text { Weight of the centrifuged material }(\mathrm{g})}{\left(\begin{array}{c}\text { Weight of the } \\ \text { sample }\end{array}\right)(\mathrm{g})-\left(\begin{array}{c}\text { Weight of the } \\ \text { evaporated residue }\end{array}\right)(\mathrm{g})}=$

$=(\mathrm{g}$ gel $/ \mathrm{g}$ dry matter $)$

WSI was determined from the evaporation of the supernatant obtained in the previous test by the following equation (Equation 3):

WSI $=\frac{\text { Weight of the residue after evaporation }(\mathrm{g})}{\text { Weight of the sample }(\mathrm{g})} \times 100$

\section{Results and discussion}

\subsection{Expansion index (IE)}

The expansion index (IE) of extruded starch is of great importance in evaluating the product quality as well as 
monitoring the extrusion process, since it is possible to verify whether the raw material used after the processing possesses suitable structure and composition for use as a food ingredient.

Analysis of variance (ANOVA) of the statistical model applied in the interaction of independent variables and the response rate of expansion index for the extruded mixture of coffee powder and rice flour is presented in Table 2.

Statistically, the variation due to the regression was significant at $95 \%$ probability level $(\mathrm{p}<0.05)$ with an estimated coefficient value $\left(\mathrm{R}^{2}\right)$ of 0.93737 , accounting for $93.737 \%$ of the total variation of the IE mean value, ascribing only $6.263 \%$ to the residues. The statistical model and experimental data were adjusted accordingly, once the variation for lack of adjustment presented no significance.

The Pareto diagram (Figure 1) shows that only the variables mixture, moisture and temperature in the linear form were statistically significant at $95 \%$ probability, presenting negative effects, which indicates that the value of IE is inversely proportional to the increase of these variables. Nevertheless, the variable mixture in the linear form caused the greatest influence on the values obtained for IE, followed by the effect of moisture and temperature.

The highest IE was obtained when the mixture was processed at $140{ }^{\circ} \mathrm{C}$ and $160{ }^{\circ} \mathrm{C}$ with $16 \%$ and $18 \%$ moisture

Table 2. Analysis of variance for the quadratic regression model of the expansion index (IE) of the extrudates of coffee powder and rice flour obtained by response surface analysis.

\begin{tabular}{lccccc}
\hline \multicolumn{1}{c}{$\begin{array}{c}\text { Source of } \\
\text { variation }\end{array}$} & $\begin{array}{c}\text { Sum of } \\
\text { squares }\end{array}$ & FD & $\begin{array}{c}\text { Means of sum } \\
\text { of squares }\end{array}$ & $\mathrm{F}_{\text {calculated }}$ & $\mathrm{F}_{\text {tabulated }}$ \\
\hline Regression & 88.112 & 9 & 9.790 & 13.303 & $3.388^{*}$ \\
Residues & 5.888 & 8 & 0.736 & & \\
Lack of adjustment & 4.211 & 5 & 0.842 & 1.507 & $9.013^{\text {n.s. }}$ \\
Pure error & 1.677 & 3 & 0.559 & - & - \\
Total & 94.000 & 17 & - & - & - \\
\hline${ }^{*}$ Significant level at 95\% probability $(\mathrm{p}<0.05)$ & n.s. $=$ non significant. &
\end{tabular}

${ }^{*}$ Significant level at $95 \%$ probability $(\mathrm{p}<0.05)$. n.s. $=$ non significant.

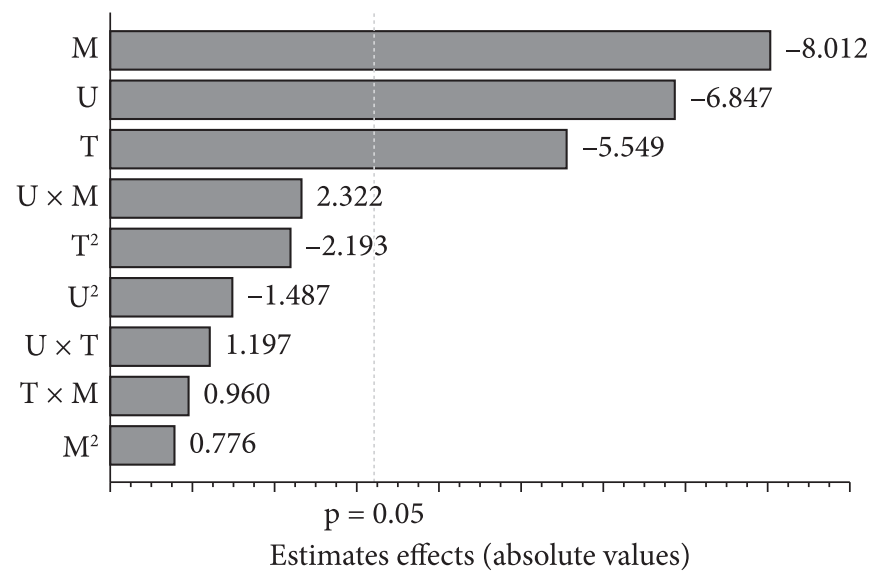

Figure 1. Estimation of linear and quadratic effects of the variables moisture (U), temperature (T) and mixture (M) upon the value of the expansion index (IE) of the extrudates of coffee powder and rice flour. and $10 \%$ and $7 \%$ coffee powder in the formulation, respectively, reaching average values of $11.11 \mathrm{~mm}$ diameter. However, the high total fiber content present in the coffee powder significantly influenced the IE of the extrudates as it increased the percentage in the mixture. Thus, samples that were processed with high moisture content $(20 \%)$, high percentage of coffee powder in the mixture $(20 \%)$ and temperature above $\left(180{ }^{\circ} \mathrm{C}\right)$ presented the lowest value of IE (2.91 mm diameter). Mendonça (2005) investigated 20 to $40 \%$ replacement levels of whole amaranth flour in the mixture with broken rice and found a low IE with increasing the content of amaranth flour in the formulation, since the product had high fiber content due to it was processed with hull.

Jeltema, Zabik and Thiel (1983) cites that food extruded formulations with ingredients of low starch and high fiber levels result in products with hard texture, increased moisture retention and reduced expansion. According to these authors, this reduction is related to the presence of components of high water-holding capacity; besides, the fiber polymers are not easy to expand.

\subsection{Water absorption index (WAI)}

The gelatinized granules absorb more water than the starch granules in their natural state. In addition, proteins may contribute to increase or decrease WAI, due to changes in their molecular structure such as changing the hydrophilichydrophobic balance, among other factors caused by extrusion (CARDOSO, 1993). Cereda, Vilpoux and Franco (2003) reported that rice starch absorbs water in the following proportions at different temperatures: $0 \%$ at $30{ }^{\circ} \mathrm{C}, 300 \%$ at $60{ }^{\circ} \mathrm{C}$ and $1000 \%$ at $70{ }^{\circ} \mathrm{C}$.

The results of the analysis of variance (ANOVA) adjusted to water absorption index of the mixture are presented in Table 3. The regression model adopted for this parameter was significant at $95 \%$ probability $(\mathrm{p}<0.05)$, presenting a multiple correlation coefficient $\left(\mathrm{R}^{2}\right)$ of 0.86918 , accounting for $86.918 \%$ of the total variation of the mean WAI; $13.082 \%$ are attributed to the residues. Therefore, the experimental data for the response variable studied pointed out a good adjustment to the quadratic model proposed.

Figure 2 shows that only the linear variable $T$ was not significant $(\mathrm{p}<0.05)$; all the other variables and their interactions contributed towards WAI variation. Nevertheless,

Table 3. Analysis of variance for the quadratic regression model to the water absorption index (WAI) of the extrudates of coffee powder with rice flour obtained by response surface analysis.

\begin{tabular}{lccccc}
\hline \multicolumn{1}{c}{$\begin{array}{c}\text { Source of } \\
\text { variation }\end{array}$} & $\begin{array}{c}\text { Sum of } \\
\text { squares }\end{array}$ & FD & $\begin{array}{c}\text { Quadratic } \\
\text { mean }\end{array}$ & $\mathrm{F}_{\text {calculated }}$ & $\mathrm{F}_{\text {tabulated }}$ \\
\hline Regression & 3.633 & 9 & 0.404 & 5.906 & $3.388 \mathrm{n} . \mathrm{s}$. \\
Residues & 0.547 & 8 & 0.068 & & \\
Lack fo adjustment & 0.530 & 5 & 0.106 & 18.584 & $9.013^{*}$ \\
Pure error & 0.017 & 3 & 0.006 & & \\
Total & 4.179 & 17 & & & \\
\hline
\end{tabular}

${ }^{*}$ Significant level at $95 \%$ probability $(\mathrm{p}<0.05)$. n.s. non significant. 
the variables that presented higher contribution indices in negative importance order were the linear variables $\mathrm{M}$ and $\mathrm{U}$ and the interactions $\mathrm{U} \times \mathrm{T}$ and $\mathrm{U} \times \mathrm{M}$, according to Pareto diagram, reflecting thus, the decrease of WAI value. However, the greatest effect was attributed to the linear variable $M$, indicating that the WAI variation was inversely proportional to the addition of coffee powder into the mixture, that is, the higher the percentage of coffee powder in the mixture the lower WAI is. Only the quadratic variables $\mathrm{M}^{2}, \mathrm{U}^{2}, \mathrm{~T}^{2}$ and the T $\mathrm{x} M$ presented positive effects, contributing towards a real increase of the WAI value.

High values of moisture during the extrusion process followed by low shearing rates reduce the attrition of the screw and the internal wall of the extruding tube upon the starch molecules. Once water acts as a lubricant in the medium, it results on lower degradation of both amylose and amylopectin and, hence, increased WAI. Therefore, the highest value of WAI (6.33 g gel/g dry matter) was obtained when the samples were processed with moisture contents of $18 \%$ and $20 \%$ and temperatures of $160^{\circ} \mathrm{C}$ and $180^{\circ} \mathrm{C}$ respectively. On the other hand, the lowest value of WAI ( $4.59 \mathrm{~g}$ gel $/ \mathrm{g}$ dry matter) was found when the mixture was processed with high moisture content and high percentage of coffee powder.

Maia et al. (1999) investigated the effect of extrusion on WAI of pre-gelatinized mixed rice and soybean hull flours. The authors found a negative interaction at WAI, that is, as increased proportions of soybean hull were added to the mixture, a decreased in WAI was observed. These results corroborate with the present study, as the total fiber present in the coffee powder decreased the water absorption index of the extruded mixture.

WAI did not decrease at temperatures of 160 and $180^{\circ} \mathrm{C}$ and with lower contents of coffee powder in the mixture (7 to $10 \%$ ). Nevertheless, when higher percentages of coffee powder were added to the process, a significant decrease of the WAI occurred. The behavior of WAI is a function of the interaction between the chemical constituents and the food system studied. With increasing temperature, solubilization of starches and denatured

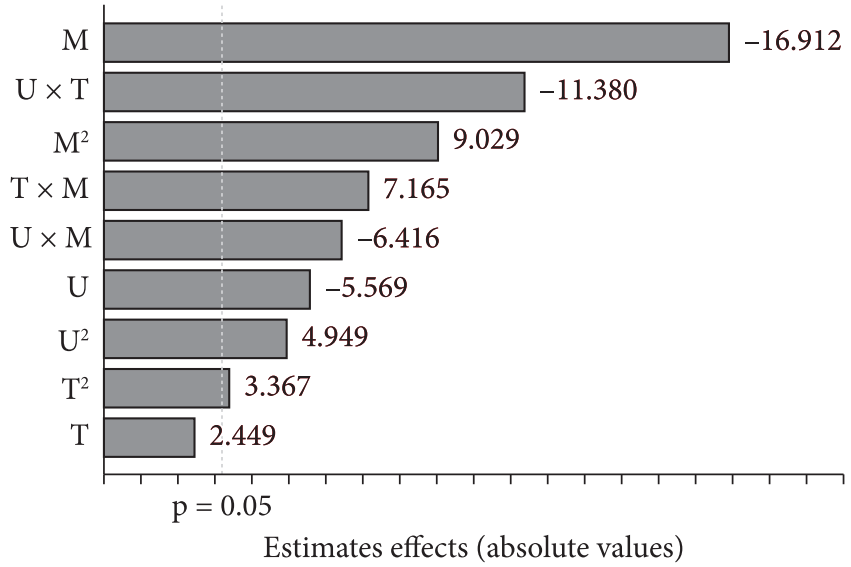

Figure 2. Estimate of the linear and quadratic effects of the variables moisture (U), temperature $(\mathbf{T})$ and mixture $(\mathbf{M})$ in the value of the water absorption value (WAI) of the extrudates of the coffee powder with rice flour. proteins take place. Thus, the effect of the total fiber, mainly in relation to the changes in water solubility and in soluble and insoluble fibers in the extrusion process must be considered.

Owusu-Ansah, Van Der Voort and Stanley (1983) observed in the extrusion process of cornstarch that the interaction between moisture and temperature had most significant effect on the responses of WAI. On the other hand, Borges (2002) and Silva (2002) extruded other sorts of mixed flours and found that the variable temperature little influenced WAI values.

Research has shown that it is very difficult to compare WAI values of different products, for they depend upon experimental conditions such as temperature, time and centrifugation speed as well as the method of sample preparation, particularly the drying process of the product (CÉSPEDES, 1999).

\subsection{Water solubility Index (WSI)}

The water solubility index is a parameter that reflects the degree of starch degradation, that is, the sum of the effects on the extrusion process of gelatinization, dextrinization and consequent solubilization (WHALEN et al., 1997).

The analysis of variance (ANOVA) in Table 4 shows the results for the quadratic regression model of WSI adjusted well to the proposed scheme. The variation due to the regression was statistically significant at $95 \%$ probability $(\mathrm{p}<0.05)$, presenting a value of determination coefficient $\left(\mathrm{R}^{2}\right)$ of 0.90317 , which accounts for $90.317 \%$ of the total variation of the response variable around the mean; $9.683 \%$ are ascribed to the residues. There is no evidence of lack of adjustment of the model to the experimental data.

In the Pareto diagram shown in Figure 3 it can be seen that the linear variable $\mathrm{T}$ and the quadratic $\mathrm{T}^{2}$ and $\mathrm{U}^{2}$ and the interaction $\mathrm{U} \times \mathrm{T}$ were not significant $(\mathrm{p}<0.05)$. All other variables contributed in a negative or positive way in the adjustment of the model.

The linear variables $U$ and $M$, due to the extrusion process, presented the highest negative values, bringing about a decrease in WSI value. However, the negative variable U affected the WSI in a greater extent, indicating that the variation of the WSI value was inversely proportional to the moisture content.

The variable $\mathrm{M}^{2}$ and the interactions $\mathrm{U} \times \mathrm{M}$ and $\mathrm{T} \times \mathrm{M}$ presented positive effect. However, the interaction $\mathrm{U} \times \mathrm{M}$ caused

Table 4. Analysis of variance for the quadratic regression model of the water solubility index (WSI) of the extruded mixture of coffee powder and rice flour obtained by response surface analysis.

\begin{tabular}{lccccc}
\hline \multicolumn{1}{c}{$\begin{array}{c}\text { Source of } \\
\text { variation }\end{array}$} & $\begin{array}{c}\text { Sum of } \\
\text { squares }\end{array}$ & FD & $\begin{array}{c}\text { Quadratic } \\
\text { mean }\end{array}$ & $\mathrm{F}_{\text {calculted }}$ & $\mathrm{F}_{\text {tabulated }}$ \\
\hline Regression & 20.709 & 9 & 2.301 & 8.291 & $3.388^{*}$ \\
Residues & 2.220 & 8 & 0.278 & & \\
Lack of adjustment & 2.040 & 5 & 0.408 & 6.798 & $9.013^{\star}$ \\
Pure error & 0.180 & 3 & 0.060 & & \\
Total & 22.929 & 17 & & & \\
\hline
\end{tabular}

*Significant level at $95 \%$ probability $(\mathrm{p}<0.05)$. n.s. non-significant. 


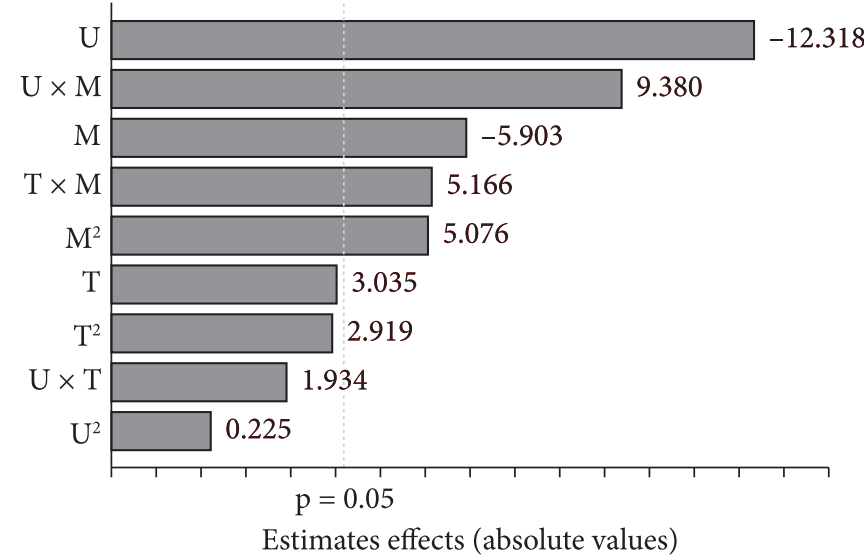

Figure 3. Estimate of the linear and quadratic effects of the variables moisture $(\mathbf{U})$, temperature $(\mathbf{T})$ and mixture $(\mathbf{M})$ in the value of the water solubility index (WSI) of the extrudates of the coffee powder and rice flour.

the greatest influence in WSI, showing that low moisture and coffee powder contents in the mixture resulted into increased WSI values.

Therefore, there is a tendency of decreasing the WSI values as a function of increased levels of moisture contents and temperature in the mixture above $15 \%$. The interaction of the variable moisture and mixture acted positively in increasing WSI values to some extent. Low values of moisture and low percentages of coffee powder into the mixture resulted in an increase of WSI values. Thus, the highest and the lowest value of WSI were obtained at 140 and $160{ }^{\circ} \mathrm{C}$ with $16 \%$ and $21 \%$ moisture and $10 \%$ and $15 \%$ coffee powder in the mixture, determining an average value of 8.57 and $4.05 \mathrm{~g}$ gel $/ \mathrm{g}$ dry matter.

Anderson et al. (1969) found that the WSI of extruded corn increases with increasing extrusion temperature when the moisture content of the mixture is low (15\%). In the experiment of these authors, moisture ranged from 15 to $25 \%$ and temperature from 121 to $229^{\circ} \mathrm{C}$. These reports are in accordance with the present study for the results obtained with the extruded mixtures of rice flour and coffee powder.

Mendonça (2005) studied different percentages of extrusion mixture of broken rice and whole amaranth flour and observed similar results to the present study.

The interactions of the variables temperature and mixture during the extrusion process were significant in the increase of WSI values, since as the temperature increased to a certain limit and the percent of coffee powder in the mixture decreased, an increase in WSI value is found. Dibós (1993) studied defatted soybean flour and found that WSI increased with increasing temperature and soybean protein content, reaching its maximum value at temperatures above $120^{\circ} \mathrm{C}$ and protein contents near $25 \%$. Souza (2003) extruded cassava flour with different percentages of Brazil nut flour and found that the increase in the percentage of nut flour in the mixture decreased WSI. These studies are in accordance with the present study, reinforcing the argument that mixtures of starch products with dietary fibers submitted to the extrusion process only produce the functional and nutritional effects when mixed at ideal concentrations and adequate processing conditions.

\section{Conclusions}

The composition of coffee powder containing high content of total fibers exerted significant influence on the extrudates of the mixtures, causing lower expansion rate. However, the higher shear rates imposed by the extrusion process in the different treatments showed that there was some modification and good cooking degree on the extruded samples. The properties of expansion index, solubility and water absorption of the extrudates showed that it is possible their use as ingredients in food products thus providing coffee flavor characteristics to the products produced from these mixtures.

\section{References}

ALVIM, I. D. Efeito da extrusão termoplástica sobre as propriedades funcionais e nutricionais de farinhas à base de milho, caseína e derivados de levedura. 2001. 104 f. Dissertação (Mestrado em Ciência da Nutrição)-Universidade Estadual de Campinas, Campinas, 2001.

ANDERSON, R. A. et al. Geletinization of corn grits by rool and extrusion cooking. Cereal Science Today, v. 14, n. 1, p. 4-12, 1969.

ASCHERI, D. P. R. et al. Obtenção de farinhas mistas pré-gelatinizadas a partir de arroz e bagaço de jabuticaba: Efeito das variáveis de extrusão nas propriedades de pasta. Boletim do CEPPA, v. 24, n. 1, p. 115-144, 2006.

ASSOCIAÇÃO BRASILEIRA DA INDÚSTRIA DE CAFÉ - ABIC. Disponível em: <http://www.abic.com.br/estatisticas.html>. Acesso em: ago. 2008.

BORGES, J. T. S. Elaboração de macarrão pré-cozido à base de farinha integral de quínoa (Chenopodium quinoa, Willd) e farinha de arroz (Oriza Sativa, $L$ ) utilizando o processo de extrusão termoplástica. 2002. 115 f. Dissertação (Mestrado em Ciência e Tecnologia de Alimentos)-Universidade Federal Rural do Rio de Janeiro, Rio de Janeiro, 2002.

BORGES, J. T. S. et al. Propriedades de cozimento e caracterização físico-química de macarrão pré-cozido à base de farinha integral de quinoa (Chenopodium quinoa, Willd) e de farinha de arroz (Oryza sativa), polido por extrusão termoplástica. Boletim do CEPPA, v. 21, n. 2, p. 303-322, 2003.

BOX, G. E. P.; DRAPER, N. R. Empirical model-building with response surface. New York: J. Wiley, 1987. 669 p.

CARDOSO, F. N. Efeito de algumas variáveis no processo de extrusão e nas características funcionais da farinha de feijão comum. 1993. 128 f. Tese (Doutorado)-Universidade Estadual de Campinas, Campinas, 1993.

CENÁRIO, M. F. C. Evolução dos custos e avaliação econômica de sistemas de irrigação utilizados na cafeicultura. In: ENCONTRO NACIONAL DE IRRIGAÇÃO DA CAFEICULTURA NO CERRADO, 6., 2000, Uberlândia. Irrigação da cafeicultura no cerrado. Uberlândia: UFU, 2001. 212 p.

CEREDA, M. P.; VILPOUX, O.; FRANCO, C. M. L. Usos de amido e seus derivados na produção de salgadinhos extrusados (snacks). In: CEREDA, M.; VILPOUX, O. Culturas de tuberosas Amiláceas Latino Americanas. São Paulo: Fundação Cargil, 2003. v. 3, cap. 6, p.132-143. 
CÉSPEDES, M. A. L. Otimização do processo de extrusão da polpa de laranja: modificações das propriedades funcionais e sua aplicação como fonte de fibra alimentar. 1999. $163 \mathrm{f}$. Tese (Doutorado em Tecnologia de Alimentos)-Faculdade de Engenharia de Alimentos, Universidade Estadual de Campinas, Campinas, 1999.

DIBÓS, A. E. L. Efeito da temperatura de extrusão e do teor de proteínas da farinha de soja desengordurada na qualidade do macarrão instantâneo de arroz. 1993. 130 f. Dissertação (Mestrado em Tecnologia de Alimentos)-Universidade de Campinas, Campinas, 1993.

FAUBION, J. M.; HOSENEY, R. C.; SEIB, P. A. Functionability of graincomponents in extrusion. Cereal Foods World, v. 27, n. 5, p. 212-216,1982.

FERNANDES, M. S. Misturas de canjiquinha e soja (80:20) e 70:30): extrusão, características tecnológicas e aplicações em alimentos. 2002. 113 f. Dissertação (Mestrado em Ciência e Tecnologia de Alimentos)-Universidade Federal Rural do Rio de Janeiro, Seropédica, 2002.

JELTEMA, M. A.; ZABIK, M. E.; THIEL, L. J. Prediction of cookie quality from dietary fiber components. Cereal Chemistry, v. 60, n. 3, p. 227-230, 1983.

LUNDUBWONG, N.; SEIB, P. A. Journal of Cereal Science. 2000, v. $31, \mathrm{p} 63$.

MAIA, L. H. et al. Viscosidade de pasta, absorção de água e índice de solubilidade em água dos mingaus desidratados de arroz e soja. Ciência e Tecnologia de Alimentos, v. 19, n. 3, p. 391-396, 1999.

MENDONÇA, X. M. F. D. A extrusão termoplástica no desenvolvimento de produtos derivados de amaranto. 2005. $203 \mathrm{f}$. Tese (Doutorado em Tecnologia de Processos Químicos e Bioquímicos)-Universidade Federal do Rio de Janeiro, Rio de Janeiro, 2005.
ORMOND, J. G. P.; PAULA, S. R. L.; FAVERET FILHO, P. Café: (re) conquista dos mercados. BNDES Setorial, Rio de Janeiro, n. 10, p. 44-45, 1999.

OWUSU-ANSAH, J.; VAN DER VOORT, F. R.; STANLEY, D. W. Physicochemical changes in corn starch as a function of extrusion variables. Cereal Chemistry, v. 60, n. 4, p. 319-324, 1983.

POLANCO, I. et al. Dieta y enfermedad celíaca. Alimentaria, v. 33, n. 264, p. 91-93, 1995.

SAES, M. S. M.; JAYO, M. Competitividade do sistema agroindustrial do café. In: FARINA, E. M. M. Q.;ZYLBERSLTAJN, D. Competitividade no agribuseness brasileiro. São Paulo: USP, 1998. v. 4, p. 3-136.

SILVA, V. L. M. Efeitos das variáveis de extrusão nas características físicas, químicas, sensoriais e nutricionais da farinha instantânea de misturas de farinha de quinoa (Chenopodium quinoa, Willd) e farinha de arroz (Oriza Sativa, L). 2002. 175 f. Tese (Doutorado em Ciência e Tecnologia de Alimentos)-Universidade Federal Rural do Rio de Janeiro, Seropédica, 2002.

SOUZA, M. L. de. Processamento de cereais matinais extrusados de castanha-do-brasil com mandioca. 2003. $191 \mathrm{f}$. Tese (Doutorado em Tecnologia de Alimentos)-Faculdade de Engenharia de Alimentos, Universidade Estadual de Campinas, Campinas, 2003.

STATSOFT. Statistica for Windows. Tulsa, OK: 1996. 1CD-ROM.

TORRES, R. L. et al. Comportamiento de variedades de arroz em la eleboración de pan sin glúten. Archivos Latinoamericano de Nutricion, v. 9, n. 2, p. 162-165, 1999.

WHALEN, P. J. et al. Measurement of extrusion effects by viscosity profile using the rapid viscoanaliser. Cereal Foods World, v. 42, n. 6, p. 469-475, 1997. 